\title{
GROUNDWATER CHEMISTRY, STORAGE AND DYNAMICS IN PARTS OF JIGAWA CENTRAL, NORTHWESTERN NIGERIA
}

\author{
Hamidu, H. ${ }^{1 *}$, Falalu, B. H. ${ }^{1}$, Abdullahi, I.M ${ }^{1}$, Kwaya, M. Y. ${ }^{1}$ and Arabi, A. S. ${ }^{2}$ \\ 1-Department of Geology, Faculty of Sciences, Usmanu Danfodiyo University, Sokoto-Nigeria \\ 2-Department of Geology, Faculty of Earth and Environmental Sciences, Bayero University, Kano-Nigeria \\ Correspondence author: *hassanhamidu@yahoo.com
}

\begin{abstract}
The Sedimentary (Chad formation) and Basement complex rocks in parts of Jigawa State were investigated for groundwater suitability for drinking, efficiency in water transmission and storage using aquifer properties derived from pumping test data using the Cooper and Jacob straight line method for single well tests. The mean values of transmissivity, hydraulic conductivity and Specific capacity recorded for the area are $4.06 \times 10^{-2} \mathrm{~m}^{2} / \mathrm{s}, 4.52 \times 10^{-3} \mathrm{~m} / \mathrm{s}$ and $1.30 \times 10^{-1} \mathrm{~m}^{2} / \mathrm{s} / \mathrm{m}$, respectively. Boreholes yield ranges between 0.20 to $1.5 \mathrm{l} / \mathrm{s}$ with an average of $0.9 \mathrm{l} / \mathrm{s}$, while drawdown ranges from 3.39 to $22.90 \mathrm{~m}$. The low values computed for these aquifer properties indicates the inefficiency and poor performance of the aquifer in the area as far as groundwater potentials and transmission are concern. This can also be attributed to the poor porosity and permeability of the parent rock from which the aquifer material were derived especially for the basement complex aquifers (weathered/fractured rocks), and the shallowness of the wells which terminate in Clayey sand or Silty aquifers with low yield. Other possible reasons include poor borehole design and the use of feldsphatic materials as gravel pack which weathers into clay over time. However, the yields can support handpump equipped wells. The water analysis revealed water of low dissolved salt and hardness that are within the recommended limit set by WHO and NIS for drinking.
\end{abstract}

Keywords: Aquifer performance, Efficiency, Hydraulic properties, Water quality, Chad formation,

\section{INTRODUCTION}

Groundwater exploration has been receiving high priority within the last three decades in Nigeria; this is because of its cheapness to harness, availability, freshness, portability and purity when compared to surface water. High intensity of groundwater development in the rural and semi urban communities in Nigeria today can be attributed to the lack of pipe borne water and dangers associated with the use of untreated surface water sources. Because of the increase in human population which led to increase in water demand, there is the need to explore groundwater sources to meet this deficit, (Aghazadeh and Mogaddam 2010).

Groundwater exploration involves, preliminary geophysical investigation drilling/development pumping test and quality/portability test. Adequate knowledge of the hydrogeology, geology complimented with geophysical data of an area is a prerequisite for successful groundwater exploration/exploitation. The quest for safe drinking water in the study area is an issue of high priority due to its geographical location and climatic conditions.

The area is covered by the sedimentary and basement complex rocks of different Hydrogeological characteristics. The concentration of mineral element in water is dependent on the geology, solubility, $\mathrm{pH}$, residence time among others, and the environment. Water is needed for different uses, the concentration of these dissolved elements in groundwater determine the type and purpose it is used for, (UNEP/WHO 1996).

Previous Hydrogeological work carried out in the area include that of Mohammed (1984) which reported a transmissivity range of 6.87 to $429.4 \mathrm{~m}^{2} /$ day for the basement complex rock and Chad formation aquifer in Kano State, he also reported that the regolith and fractures in the fresh basement are interconnected at certain depth. Wright and Burgess (1992) design a weathering profile grade for the basement complex rocks of Kano State; they identified three water bearing layers based on depth of weathering zones which are designated as IV III and IIa zones, with IIa being the best because of low clay (15\%). Hazell et al. in Wright and Burgess (1992) reported that rock types do control the aquifer characteristics and the extent of kaolinization of feldspars in granite largely controls the yield of boreholes and water quality, for the basement rock of Kano state, the pink feldsphatic granite is a better aquifer compared with the whitish feldspar variety. Offodile (2002) estimated the depth of boreholes in the basement rock of Danbatta area of Kano state to be between 40-50 m with a lithology that compose of coarse quartz, sand and gravels with decomposed granite at the bottom. He went further to measure the yield of two boreholes in the area to be 6.3 and $9.1 \mathrm{l} / \mathrm{s}$ he attributed such high yields to the presence of alluvial beds or deeply fractured zones. 
Akaha and Promise (2008) reported a poor yield and hydraulic characteristics for Azare town located in the Kerri- Kerri formation within the Chad formation of the Hade-Jama'are basin, with Transmissivity and hydraulic conductivity that ranges between $7.39 \times 10^{-6}$ and $3.55 \times 10^{-4} \mathrm{~m}^{2} / \mathrm{sec}, 5.62 \times 10^{-7}$ and $42.54 \times 10^{-5} \mathrm{~m} / \mathrm{sec}$ respectively, with an average Specific capacity value of $2.10 \times 10^{-4} \mathrm{~m}^{3} / \mathrm{sec} / \mathrm{m}$, this low values were attributed to the presence of clay and clayey sand lithology within the Kerri- Kerri formation, this they believe is responsible for the reduction of the aquifer efficiency which is largely due to the fine particles found within the aquifer.

Bala (2008) studied the optimum depth of boreholes in regolith aquifers of the basement complex of northern Nigeria where he reported that the greater the depth to water table in a borehole, the lesser the yield and the deeper the borehole. He recommended an optimum depth of $40 \mathrm{~m}$ and an estimated yield of 40 litres per minutes for the basement terrain. Abubakar and Yola (2012) identified five geoelectric layers for Dawakin Tofa area of Kano State; these consist from the top; a lateritic layer, top soil or lateritic sand, silty sand or sandy clay, fractured basement and fresh basement, with an average thickness $14.33 \mathrm{~m}$ and an average resistivity value of $\mathrm{s} 178 \Omega \mathrm{m}$. However Yelwa et al. (2015) identified two water bearing zones for Kumbotso area of Kano state, weathered and fractured basement layer with resistivity range of between $6 \Omega \mathrm{m}$ and $265 \Omega \mathrm{m}$ and average thickness of 19 and $15 \mathrm{~m}$, respectively.

This present research intend to study in details the hydrogeology of the crystalline and sedimentary formations in the area and to compare their groundwater potentials, this will be achieved by the use of pumping test data to determine the hydraulic parameters of the aquifers and also to evaluate the performance and productivity of the boreholes in the different Hydrogeological environments. A preliminary assessment of the groundwater quality for drinking purpose will be carried out and compared with NIS and WHO standards.

\section{MATERIALS AND METHODS Location and Geomorphology of Study area}

The area of study falls within Jigawa central of Jigawa state. It is located within the savannah vegetation belt of Northern Nigeria with an annual rainfall range of between 750-1000 mm (New and Hulsne, 1997), the southwestern part receives an average of 80 rainy days annually while the northern part of the area toward the Lake Chad receives 40 days of rains (Offodile, 2002). Topographically, the area is characterized by rocky Hills and Inselbergs at its southwestern end with an elevation that ranges between $400-500 \mathrm{~m}$ within the basement area. The northern to northeastern half of the area consist of low lying monotonous undulating sand dunes of various sizes which span for several kilometres within the sedimentary Chad formation (Offodile, 2002), Hydrology of Jigawa state consists of two main rivers: the Hadejia- Kafin Hausa and Iggi river systems with many tributaries which feed extensive marshland in the northeastern part of the state, The Hadejia- Kafin Hausa traverses the state from west to east through the Hadejia-Nguru wetlands and empties into the Lake Chad, Fig.1.

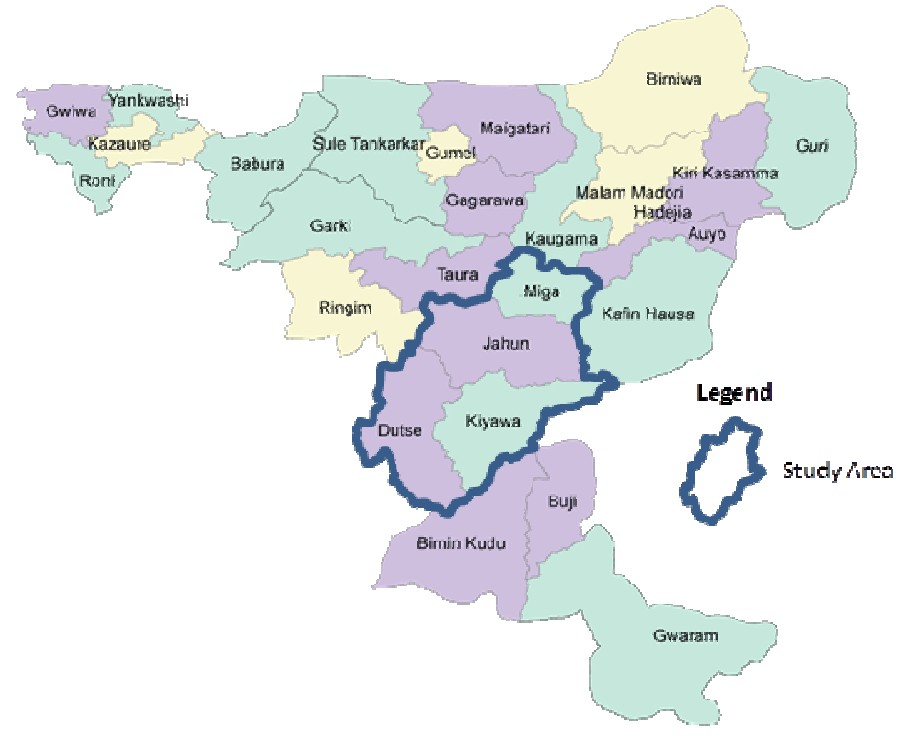

Figure 1: Modified Map of Jigawa State showing the local Government areas of study Geology and hydrogeology of the study area

\section{Geology of the study area}

Geologically, the area is located within the Hadejia Yobe basin which structurally is a triangular basin with its apex in the northeast of Nigeria, roughly coinciding with the west end of the Chad basin, and forms the southwestern arm of the Lake Chad basin Nigeria, (Offodile, 2002). The area of study is underlain by both crystalline and sedimentary rock. 
The Quaternary Chad formation consists mainly of Clays, Sandy clay and Siltstones with lenses of Sand and gravels occurring at different depths with a maximum thickness of $165 \mathrm{~m}$, (Offodile 2002). The pre Cambrian basement complex rocks in the area are made up of granite, granite porphyry, medium to coarse grained hornblende biotite granite and coarse porphyritic biotite granite Fig 2.

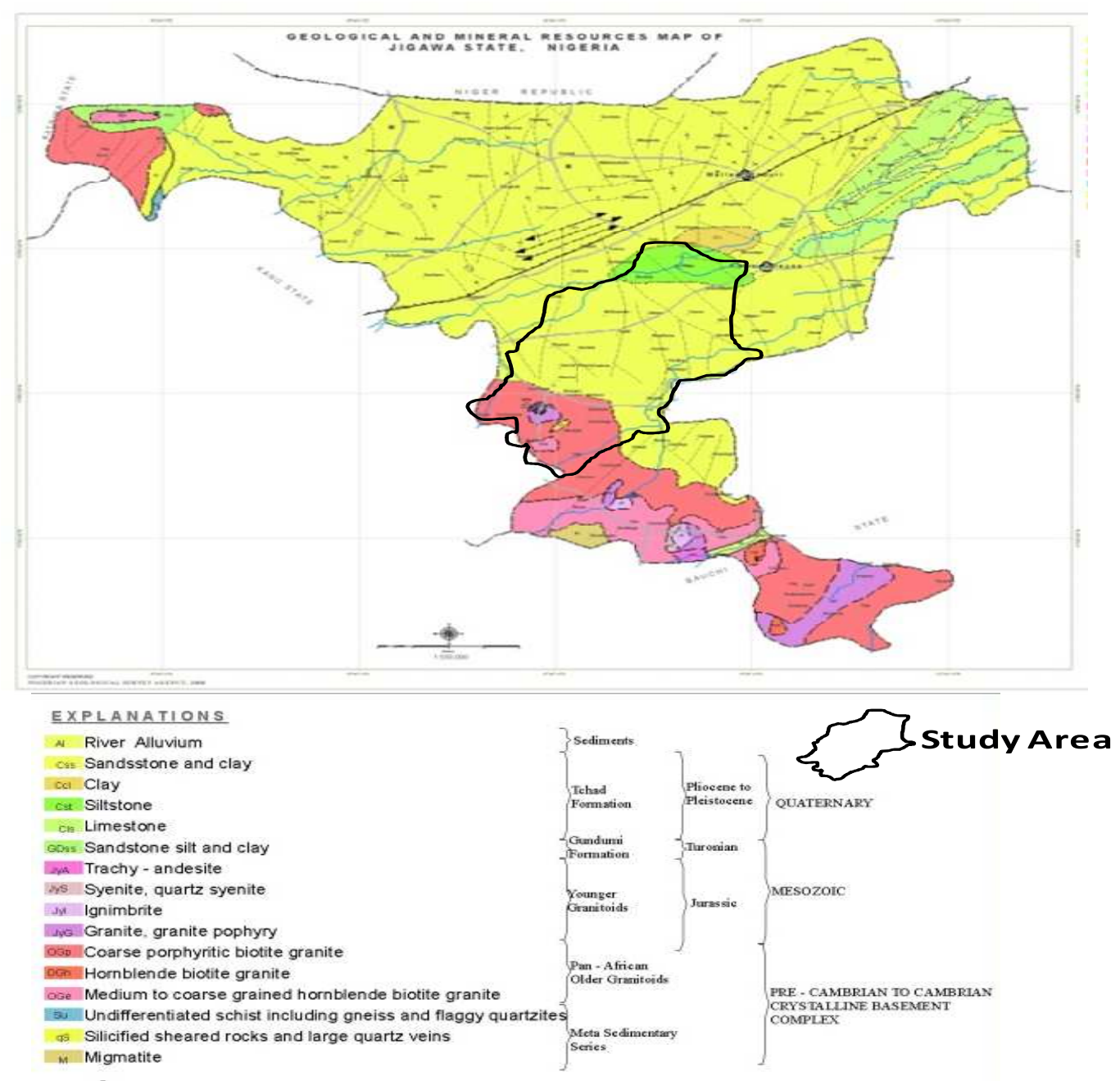

Figure 2: Geologic Map of Jigawa State showing the study area (modified from geological and mineral resources Map of Jigawa state of Nigeria Geological survey agency 2006)

\section{Hydrogeology of the study area}

The groundwater in the area is located in two Hydrogeological units the sedimentary and basement aquifers with two distinct characteristics in terms of groundwater potentials. However these aquifers all depend on natural precipitation or artificially sources through irrigation of the land for their recharge and sustainability or in some instances through percolation of surface water bodies like rivers or streams (loosing), ponds or Dams, while discharge are through dug wells, boreholes or spring sources.

\section{Sources of Data}

The data and information on the pumping test used for this research work were obtained from the rural water and sanitation agency (RUWASA) of Jigawa state and Hadeja Jama'are river basin authority. Submersible pump, plastic bucket of known volume, stopwatch and a dip meter were used to carry out the pumping test at each of the sites while the preliminary water quality and bacteriological assessment for drinking was carried out at the Jigawa State Water Board water quality control laboratory, Birnin- Kudu. Materials used during sampling includes PH and Conductivity meters for measuring PH, Conductivity and Temperatures of samples on sites, while the Flame photometer was used to analysed the Cations in the laboratory. One litre Plastic containers were used for the collection of water samples in the field. 


\section{Determination of Aquifer Properties}

To determine the aquifer properties of Transmissivity, Hydraulic conductivity and Specific conductivity, a total of 36 pumping test data were obtained for single well tested boreholes that were conducted in the study area. Each borehole was pumped tested for a period of 120 minutes until equilibrium was reached in the pumping well. The Cooper-Jacob non-equilibrium steady flow method for single well test was adopted for this research. The method is less tedious and yields reliable estimate of transmissivity value compared with other methods. Theis approximation method was used; the drawdown values obtained for the pumping phase were plotted against the time on a semi-log graph sheet to determine the slope $\Delta s$. The value of the slope obtained for the individual borehole was used in computing the transmissivity of the aquifer materials in the study area. Early pumping time was avoided when the slope was determined, because most of the time represents water that is released from well bore storage which tend to mask the real water flowing from aquifer storage. For this study the mid and late times drawdown values were used, the best straight line obtained from joining the drawdown values was considered and the slope per log cycle was calculated (Figure 3 ). The transmissivity was determined by using the modified Theis non-equilibrium equation of Cooper- Jacob (1946) given as:

$\mathrm{T}=\frac{2.30 Q}{4 \pi \Delta s}$

Where $\mathrm{T}=$ Transmissivity in $\mathrm{m}^{2} / \mathrm{s}$

$\mathrm{Q}=$ Borehole Discharge or Yield in $\mathrm{l} / \mathrm{s}$

$\Delta s=$ Slope

Based on the formula given by Kruseman and Ridder (2000) Hydraulic conductivity was determined from the relation;

$\mathrm{K}=\mathrm{T} / \mathrm{B}$

Where $\mathrm{K}=$ Hydraulic conductivity

$B=$ Saturated aquifer thickness or Screen length used.

Specific capacity was calculated using:

$\mathrm{Q} / \mathrm{s}$

$\mathrm{S}=$ total drawdown recorded in pumping well

Surfer 11 Software was used to plot the drawdowntime curves generated for the individual boreholes pumped tested.

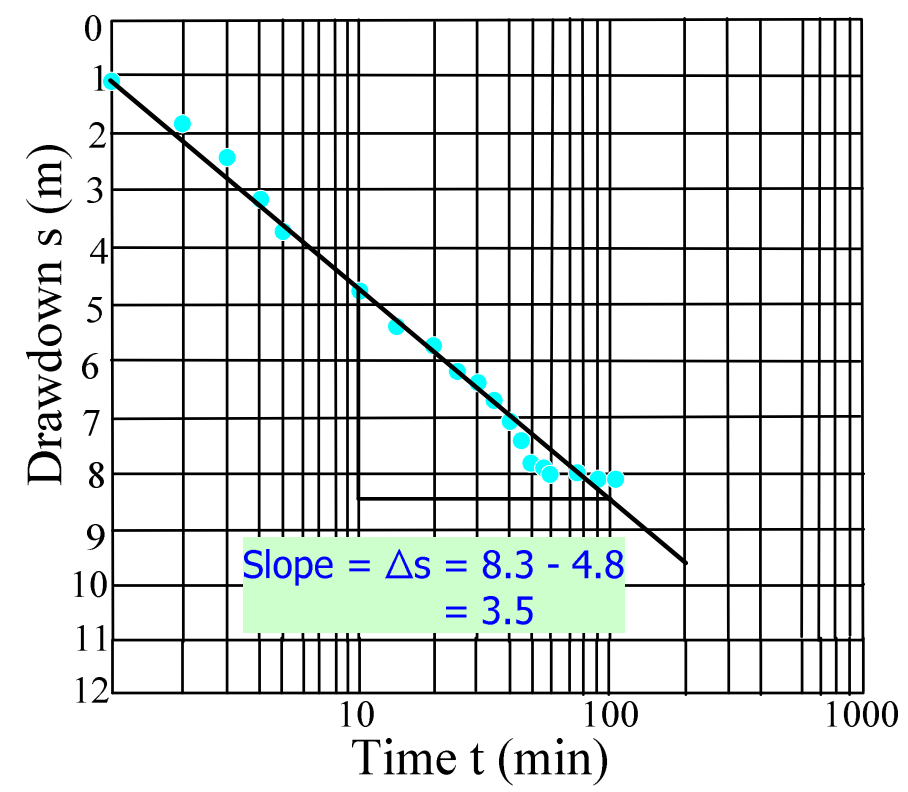

Figure 3: A Semi-log graph showing a straight line plot of Drawdown against Time for the single tested borehole at Dangyatin town

In order to determine the quality of water for drinking and domestic uses, 30 water samples were collected and subjected to physicochemical and bacteriological analysis at the Jigawa state water board water quality control laboratory Birnin-Kudu. Flame photometry was used to determine the Cations and the anions were determined through the use of titrimetric method.

\section{RESULTS AND DISCUSSION}

The results of the research for both the aquifer analysis and groundwater physicochemical analysis are summarized and presented in Tables 1 and 2 below. 
BAJOPAS Volume 10 Number 1 June, 2017

\section{Aquifer characteristics}

\section{Yield}

The yield of boreholes in the area of study ranges from 0.20 to $1.5 \mathrm{l} / \mathrm{s}$, the yield range for the boreholes located in the sedimentary formation is between 0.34 and 1.5 $\mathrm{I} / \mathrm{s}$ with a mean of 0.97 , while the basement aquifer the range is between $0.20-1.20 \mathrm{l} / \mathrm{s}$ with an average of 0.58 $\mathrm{l} / \mathrm{s}$. The average yield for the area of study is $0.90 \mathrm{l} / \mathrm{s}$

\section{Drawdown}

The value of drawdown falls between 3.39 to $22.90 \mathrm{~m}$ in the area, the sedimentary Chad formation in the area have values of drawdown is between $3.39-12.00 \mathrm{~m}$, the basement aquifers values are from 13.10 to $22.90 \mathrm{~m}$.

\section{Transmissivity}

This aquifer property calculated for both the sedimentary Chad formation and basement aquifers in the area have a range of between $1.10 \times 10^{-2}$ and $5.23 \times 10^{-1} \mathrm{~m}^{2} / \mathrm{s}$, the value range for the sedimentary formation in the study area is $1.26 \times 10^{-2}$ and $5.23 \times 10^{-1}$ $\mathrm{m}^{2} / \mathrm{s}$. The range for the basement aquifer on the other hand is from $1.10 \times 10^{-2}$ to $2.80 \times 10^{-1} \mathrm{~m}^{2} / \mathrm{s}$, while the mean for the area is $4.06 \times 10^{-2} \mathrm{~m}^{2} / \mathrm{s}$.

\section{Hydraulic conductivity}

This parameter ranges in value between $1.05 \times 10^{-3}$ and $5.81 \times 10^{-2} \mathrm{~m} / \mathrm{s}$, the sedimentary Chad formation in the area have the same range as above. The basement aquifers have a range that varies between $1.15 \times 10^{-3}$ and $3.10 \times 10^{-2} \mathrm{~m} / \mathrm{s}$ and the average for the area of study is $4.52 \times 10^{-3} \mathrm{~m} / \mathrm{s}$.

\section{Specific capacity}

Values calculated for the area ranges between $1.81 \times 10^{-}$

2 and $9.30 \times 10^{-1} \mathrm{~m}^{2} / \mathrm{s} / \mathrm{m}$, sedimentary aquifer value range is between $2.52 \times 10^{-2}$ and $9.30 \times 10^{-1} \mathrm{~m}^{2} / \mathrm{s} / \mathrm{m}$, the values for the basement aquifers in the area ranges between $1.81 \times 10^{-2}$ and $2.80 \times 10^{-1} \mathrm{~m}^{2} / \mathrm{s} / \mathrm{m}$ while the average calculated for the area is $1.30 \times 10^{-1} \mathrm{~m}^{2} / \mathrm{s} / \mathrm{m}$.

\section{Water quality analysis Physical parameters}

The $\mathrm{pH}$ values measured in the samples ranges from 6.47 to 7.80 with an average of 7.23 , Temperature measured are between 31 and $34.1{ }^{\circ} \mathrm{C}$ with an average of $32.5^{\circ} \mathrm{C}$. Total Dissolved Solids (TDS) measured in water is between 97.80 and $261.37 \mathrm{mg} / \mathrm{l}$ with a mean of $110.83 \mathrm{mg} / \mathrm{l}$. The Electric conductivity of the sampled water has a range that varies between 142 to $352 \mu S$ $/ \mathrm{cm}$ with a mean of $228 \mu \mathrm{S} / \mathrm{cm}$. Total hardness measured for the samples are from 37.80 to 113.50 $\mathrm{mg} / \mathrm{l}$ with an average of $73 \mathrm{mg} / \mathrm{l}$. Bacteriological analysis reveals a total bacterial count range of between 2 and $3 \mathrm{Cfu} / 100 \mathrm{mil}$ with an average value of $2.8 \mathrm{Cfu} / 100 \mathrm{mil}$ for the 26 water samples analyzed.

\section{Chemical parameters}

Calcium $\left(\mathrm{Ca}^{2+}\right)$ and Magnesium ( $\mathrm{Mg}^{2+}$ ) have concentration ranges of between $9.48-29.20 \mathrm{mg} / \mathrm{l}$ and 3.86 to $9.80 \mathrm{mg} / \mathrm{l}$ with averages of 18.20 and 6.90 $\mathrm{mg} / \mathrm{l}$, respectively. The total iron concentration ranged between 0.001 and $0.21 \mathrm{mg} / \mathrm{l}$ with an average of 0.05 $\mathrm{mg} / \mathrm{l}$.

Chloride $(\mathrm{Cl})$ have concentration that varies between 2.50 and $10.00 \mathrm{mg} / \mathrm{l}$ with a mean value of $5.50 \mathrm{mg} / \mathrm{l}$, while Sulphate $\left(\mathrm{SO}_{4}{ }^{2-}\right)$ concentration ranges between 0.42 and $10.00 \mathrm{mg} / \mathrm{l}$ in the water sampled with an average value of $4.01 \mathrm{mg} / \mathrm{I}$. $\left(\mathrm{NO}^{-3}\right)$ has a concentration between 0.001 and $0.06 \mathrm{mg} / \mathrm{l}$ with an average of 0.008 $\mathrm{mg} / \mathrm{l}$ while the concentration range for $\mathrm{NO}_{2}$ is between 0.30 and $6.20 \mathrm{mg} / \mathrm{l}$ with a mean of $2.10 \mathrm{mg} / \mathrm{l}$ for the thirty water samples analysed, Table 2. 
BAJOPAS Volume 10 Number 1 June, 2017

Table 1: Boreholes Characteristics and Aquifer Hydraulic Properties of the Study Area

\begin{tabular}{|c|c|c|c|c|c|c|c|c|c|c|c|}
\hline $\mathbf{S} / \mathbf{N}$ & Location Name & LGA & $\begin{array}{l}\text { Static } \\
\text { water } \\
\text { level } \\
\text { (m) }\end{array}$ & $\begin{array}{l}\text { Draw } \\
\text { down } \\
\text { (m) }\end{array}$ & $\begin{array}{l}\text { Total } \\
\text { Depth } \\
\text { (m) }\end{array}$ & $\begin{array}{l}\text { Yield } \\
Q(1 / s)\end{array}$ & $\begin{array}{l}\text { Screen } \\
\text { length } \\
\text { (m) }\end{array}$ & $\begin{array}{l}\text { Transmissivity } \\
T\left(\mathbf{m}^{2} / \mathbf{s}\right)\end{array}$ & $\begin{array}{l}\text { Hydraulic } \\
\text { Conductivity } \\
K(m / s)\end{array}$ & $\begin{array}{l}\text { Specific } \\
\text { capacity } \\
\left(\mathrm{m}^{2} / \mathrm{s} / \mathrm{m}\right)\end{array}$ & $\begin{array}{l}\text { Formation } \\
\text { Type/Aquifer }\end{array}$ \\
\hline 1 & Dangyatinpri School & Miga & 10.2 & 5.75 & 42 & 1.2 & 9 & $1.32 \times 10^{-1}$ & $1.46 \times 10^{-2}$ & $2.10 \times 10^{-1}$ & Chad formation \\
\hline 2 & DangyatinUng Garba & Miga & 9.9 & 8.05 & 42 & 1.48 & 9 & $8.00 \times 10^{-2}$ & $8.59 \times 10^{-3}$ & $1.84 \times 10^{-1}$ & Chad formation \\
\hline 3 & YandunaPHC Clinic & Miga & 9.2 & 9.4 & 42 & 1.3 & 9 & $5.53 \times 10^{-2}$ & $6.15 \times 10^{-3}$ & $3.83 \times 10^{-1}$ & Chad formation \\
\hline 4 & Yandunakofargabas & Miga & 8.1 & 7 & 42 & 1.2 & 9 & $8.61 \times 10^{-2}$ & $9.56 \times 10^{-3}$ & $1.71 \times 10^{-1}$ & Chad formation \\
\hline 5 & Rigar Rama & Miga & 6.23 & 7.99 & 45.7 & 1 & 9 & $8.00 \times 10^{-2}$ & $8.80 \times 10^{-3}$ & $1.25 \times 10^{-1}$ & Chad formation \\
\hline 6 & Jigawar Fulani & Miga & 12.5 & 14.37 & 46 & 1.2 & 9 & $4.22 \times 10^{-2}$ & $4.69 \times 10^{-3}$ & $8.40 \times 10^{-1}$ & Chad formation \\
\hline 7 & Sarawuya & Miga & 5.11 & 12.61 & 48.3 & 1.22 & 9 & $1.86 \times 10^{-1}$ & $2.10 \times 10^{-2}$ & $9.70 \times 10^{-2}$ & Chad formation \\
\hline 8 & Malikawa & Miga & 7.76 & 14.13 & 50 & 1.08 & 9 & $4.03 \times 10^{-2}$ & $4.48 \times 10^{-3}$ & $7.64 \times 10^{-2}$ & Chad formation \\
\hline 9 & Danbusanpri School & Kiyawa & 17.3 & 7.05 & 45 & 1 & 9 & $3.00 \times 10^{-2}$ & $3.29 \times 10^{-3}$ & $8.33 \times 10^{-2}$ & Chad formation \\
\hline 10 & DanbusanPHC Clinic & Kiyawa & 18.05 & 12 & 42 & 1.2 & 9 & $6.00 \times 10^{-2}$ & $6.50 \times 10^{-3}$ & $1.70 \times 10^{-1}$ & Chad formation \\
\hline 11 & KatukaPHC Clinic & Kiyawa & 11.2 & 10.4 & 45 & 1.25 & 9 & $5.00 \times 10^{-2}$ & $5.52 \times 10^{-3}$ & $1.20 \times 10^{-1}$ & Chad formation \\
\hline 12 & KatukaUng.Madaki & Kiyawa & 10.6 & 11.45 & 42 & 1.5 & 9 & $5.10 \times 10^{-2}$ & $5.65 \times 10^{-3}$ & $1.31 \times 10^{-1}$ & Chad formation \\
\hline 13 & Andazakoki & Kiyawa & 8.4 & 11.95 & 42 & 1 & 9 & $6.00 \times 10^{-2}$ & $6.55 \times 10^{-3}$ & $8.40 \times 10^{-2}$ & Chad formation \\
\hline 14 & Andazagabas 2 & Kiyawa & 10.2 & 10.55 & 42 & 1.5 & 9 & $4.43 \times 10^{-2}$ & $4.91 \times 10^{-3}$ & $1.42 \times 10^{-1}$ & Chad formation \\
\hline 15 & $\begin{array}{l}\text { Turakawaduniya } \\
\text { T/wada }\end{array}$ & Jahun & 17.1 & 8.6 & 42 & 0.9 & 9 & $9.00 \times 10^{-2}$ & $9.89 \times 10^{-3}$ & $9.30 \times 10^{-1}$ & Chad formation \\
\hline 16 & $\begin{array}{l}\text { Turakawa } \\
\text { duniyaTinubu }\end{array}$ & Jahun & 19.1 & 8.7 & 42 & 1 & 9 & $5.23 \times 10^{-1}$ & $5.81 \times 10^{-2}$ & $1.15 \times 10^{-1}$ & Chad formation \\
\hline 17 & Idanduna pri school & Jahun & 23.65 & 15.05 & 48 & 0.38 & 12 & $1.26 \times 10^{-2}$ & $1.05 \times 10^{-3}$ & $2.52 \times 10^{-2}$ & Chad formation \\
\hline 18 & Idanduna masanlaci & Jahun & 24.5 & 13 & 45 & 0.38 & 9 & $1.83 \times 10^{-2}$ & $2.03 \times 10^{-3}$ & $3.00 \times 10^{-2}$ & Chad formation \\
\hline 19 & Gidanduka & Jahun & 21.6 & 11.05 & 48 & 0.8 & 12 & $5 . .05 \times 10^{-2}$ & $4.21 \times 10^{-3}$ & $7.24 \times 10^{-2}$ & Chad formation \\
\hline 20 & Gidanduka II & Jahun & 20.8 & 10.6 & 48 & 0.6 & 12 & $2.74 \times 10^{-2}$ & $2.28 \times 10^{-3}$ & $5.70 \times 10^{-2}$ & Chad formation \\
\hline 21 & Dukkana duniya kudu & Jahun & 39.8 & 5 & 60 & 0.5 & 12 & $4.00 \times 10^{-2}$ & $3.24 \times 10^{-3}$ & $1.00 \times 10^{-1}$ & Chad formation \\
\hline 22 & $\begin{array}{l}\text { Dukkana duniya } \\
\text { arewa }\end{array}$ & Jahun & 38.6 & 6.65 & 60 & 0.6 & 12 & $6.10 \times 10^{-2}$ & $5.08 \times 10^{-3}$ & $9.02 \times 10^{-2}$ & Chad formation \\
\hline 23 & Abasha & Jahun & 9 & 12 & 45.7 & 1.1 & 9 & $4.70 \times 10^{-2}$ & $5.20 \times 10^{-3}$ & $9.20 \times 10^{-2}$ & Chad formation \\
\hline 24 & Garado & Jahun & 4.34 & 18.95 & 45.7 & 1 & 9 & $4.26 \times 10^{-2}$ & $4.73 \times 10^{-3}$ & $5.30 \times 10^{-2}$ & Chad formation \\
\hline 25 & Chamopri School & Dutse & 26.2 & 8.4 & 40 & 1.2 & 9 & $7.32 \times 10^{-2}$ & $8.13 \times 10^{-3}$ & $1.43 \times 10^{-1}$ & Chad formation \\
\hline 26 & Chamo kofar gabas & Dutse & 25.5 & 6.9 & 42 & 1 & 9 & $3.05 \times 10^{-2}$ & $3.38 \times 10^{-3}$ & $1.45 \times 10^{-1}$ & Chad formation \\
\hline 27 & $\begin{array}{l}\text { Dundubus health } \\
\text { center }\end{array}$ & Dutse & 15.7 & 13.1 & 42 & 0.5 & 9 & $2.13 \times 10^{-2}$ & $2.36 \times 10^{-3}$ & $2.70 \times 10^{-2}$ & Basement \\
\hline 28 & Dundubus community & Dutse & 12.2 & 18.6 & 42 & 0.5 & 9 & $2.20 \times 10^{-1}$ & $2.42 \times 10^{-2}$ & $3.82 \times 10^{-2}$ & Basement \\
\hline 29 & Karnayacikingari & Dutse & 11.2 & 19.05 & 42 & 0.4 & 9 & $2.00 \times 10^{-2}$ & $2.14 \times 10^{-3}$ & $2.10 \times 10^{-2}$ & Basement \\
\hline 30 & KarnayaBabbanlayi & Dutse & 10.3 & 22.05 & 45 & 0.4 & 9 & $1.26 \times 10^{-2}$ & $1.46 \times 10^{-3}$ & $1.81 \times 10^{-2}$ & Basement \\
\hline 31 & Nuhu sunusi pri school & Dutse & 5.6 & 22.9 & 42 & 1.2 & 9 & $2.50 \times 10^{-2}$ & $2.77 \times 10^{-3}$ & $5.24 \times 10^{-2}$ & Basement \\
\hline 32 & Nuhu sunusi sabuwar & Dutse & 10 & 15.8 & 32 & 0.3 & 9 & $1.04 \times 10^{-2}$ & $1.15 \times 10^{-3}$ & $2.00 \times 10^{-2}$ & Basement \\
\hline 33 & Nahuche & Dutse & - & 10.1 & 30 & 0.2 & 9 & $1.83 \times 10^{-2}$ & $2.03 \times 10^{-3}$ & $2.00 \times 10^{-2}$ & Basement \\
\hline 34 & Kaigama & Dutse & - & 3.39 & 38 & 0.95 & 12 & $1.10 \times 10^{-2}$ & $9.05 \times 10^{-3}$ & $2.80 \times 10^{-1}$ & Basement \\
\hline 35 & Misanya & Dutse & - & 3.66 & 30.1 & 0.9 & 9 & $2.80 \times 10^{-1}$ & $3.10 \times 10^{2}$ & $2.46 \times 10^{-1}$ & Basement \\
\hline \multirow[t]{2}{*}{36} & Amuga & Dutse & - & 10.36 & 29.4 & 0.49 & 9 & $3.60 \times 10^{-2}$ & $3.98 \times 10^{-3}$ & $4.73 \times 10^{-3}$ & Basement \\
\hline & $\begin{array}{l}\text { Minimum } \\
\text { Maximum } \\
\text { Average }\end{array}$ & & & & & & & $4.06 \times 10^{-2}$ & $\begin{array}{l}1.05 \times 10^{-3} \\
5.81 \times 10^{-2} \\
4.52 \times 10^{-3}\end{array}$ & $\begin{array}{l}1.81 \times 10^{-} \\
9.30 \times 10^{-1} \\
1.30 \times 10^{-1}\end{array}$ & \\
\hline
\end{tabular}


BAJOPAS Volume 10 Number 1 June, 2017

Table 2: Summary of Physicochemical Analysis Results of Groundwater Samples from the Study Area

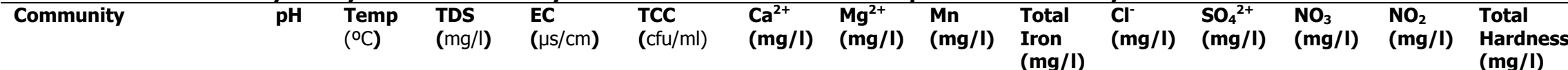

\begin{tabular}{|c|}
\hline $\begin{array}{l}\text { Dangyatin pri. School } \\
\text { Dangyatin ung Garba } \\
\text { Yanduna Clinic } \\
\text { Yanduna kafar gabas } \\
\text { Danbusan pri. School } \\
\text { Danbusan Clinic } \\
\text { Katuka Clinic } \\
\text { Katuka ung. Madaki } \\
\text { Andaza Koki } \\
\text { Andaza gabas } \\
\text { Turankawa Duniya T/wada } \\
\text { Turankawa Duniya Tinibu } \\
\text { Idonduna Pri.School } \\
\text { Idonduna Masallaci } \\
\text { Gidanduka } \\
\text { Gidanduka II } \\
\text { Dukkanna duniya Kudu } \\
\text { Dukkana duniya Arewa } \\
\text { Dundubus health centre } \\
\text { Dundubus JSS } \\
\text { Karnaya cikin gari } \\
\text { Karnaya babban layi } \\
\text { Nuhu Sunusi pri. School } \\
\text { Nuhu Sunusi sabuwar } \\
\text { maran } \\
\text { Chamo pri. School } \\
\text { Chamo kofar gabas } \\
\text { Jigawar Fulani } \\
\text { Sarawuya } \\
\text { Malikawa } \\
\text { Rafin rima }\end{array}$ \\
\hline
\end{tabular}

$\begin{array}{lllll}7.10 & 34.1 & 244.86 & 318 & 3 \\ 6.71 & 31.0 & 165.54 & 215 & 2 \\ 6.51 & 32.7 & 173.25 & 225 & 3\end{array}$

$\begin{array}{lllllllll}22.7 & 5.64 & 0.00 & 0.18 & 9.00 & 8.00 & 0.02 & 3.10 & 79.50 \\ 14.06 & 6.51 & 0.00 & 0.15 & 4.10 & 3.90 & 0.002 & 1.00 & 61.70 \\ 17.12 & 6.09 & 0.00 & 0.20 & 6.10 & 3.90 & 0.001 & 0.50 & 67.60 \\ 21.80 & 7.90 & 0.00 & 0.15 & 6.50 & 10.0 & 0.001 & 0.45 & 88.40 \\ 8.83 & 3.86 & 0.00 & 0.00 & 2.10 & 0.42 & 0.00 & 0.31 & 37.80\end{array}$

$\begin{array}{llll}6.47 & 32.1 & 271.04 & 352 \\ 6.73 & 31.7 & 97.81 & 127\end{array}$

$\begin{array}{llll}6.73 & 31.7 & 97.81 & 127\end{array}$

$\begin{array}{llll}7.10 & 32.0 & 109.34 & 142\end{array}$

$\begin{array}{llll}6.93 & 32.0 & 148.61 & 193 \\ 7.10 & 33.0 & 138.60 & 180\end{array}$

$\begin{array}{llll}6.87 & 31.4 & 145.53 & 189\end{array}$

$\begin{array}{llll}6.91 & 33.1 & 126.28 & 164\end{array}$

$\begin{array}{llll}6.71 & 31.9 & 261.37 & 281\end{array}$

$\begin{array}{llll}6.59 & 33.2 & 225.61 & 293\end{array}$

$\begin{array}{llll}6.83 & 31.8 & 143.22 & 186\end{array}$

$\begin{array}{llll}6.92 & 32.4 & 170.17 & 221\end{array}$

$\begin{array}{llll}6.49 & 32.3 & 147.84 & 192\end{array}$

$\begin{array}{llll}7.12 & 34.1 & 215.60 & 280 \\ 6.98 & 33.7 & 191.73 & 249\end{array}$

$\begin{array}{llll}6.98 & 33.7 & 191.73 & 249 \\ 7.30 & 32.3 & 239.47 & 311\end{array}$

$\begin{array}{llll}7.26 & 33.1 & 226.38 & 294\end{array}$

$\begin{array}{llll}7.29 & 32.1 & 180.18 & 234\end{array}$

$\begin{array}{llll}7.40 & 31.8 & 164.01 & 213 \\ 7.60 & 31.8 & 185.57 & 241\end{array}$

$\begin{array}{llll}7.60 & 31.8 & 185.57 & 241 \\ 7.80 & 33.1 & 231.75 & 301\end{array}$

$\begin{array}{llll}7.40 & 32.1 & 110.87 & 144\end{array}$

$\begin{array}{llll}6.71 & 32.6 & 162.47 & 211\end{array}$

$\begin{array}{llll}7.30 & 29.4 & 169.40 & 220 \\ 7.40 & 29.0 & 207.90 & 270\end{array}$

$\begin{array}{llll}6.94 & 29.1 & 161.70 & 210 \\ 7.13 & 30.0 & 154.78 & 201\end{array}$

Table 3: WHO and NIS Drinking Water Maximum Permissible Limits

\begin{tabular}{|c|c|c|c|c|c|c|c|c|c|c|c|c|c|c|}
\hline Parameters & pH & $\begin{array}{l}\text { Temp } \\
{ }^{\circ} \mathrm{C}\end{array}$ & $\begin{array}{l}\text { TDS } \\
(\mathrm{mg} / \mathrm{I})\end{array}$ & $\begin{array}{l}\text { EC } \\
(\mu \mathrm{s} / \mathrm{cm})\end{array}$ & $\begin{array}{l}\text { TCC } \\
\text { (cfu/ml) }\end{array}$ & $\begin{array}{l}\mathrm{Ca}^{2+} \\
(\mathrm{mg} / \mathrm{I})\end{array}$ & $\begin{array}{l}\mathrm{Mg}^{2+} \\
(\mathrm{mg} / \mathrm{l})\end{array}$ & $\begin{array}{l}\mathrm{Mn} \\
(\mathrm{mg} / \mathrm{I})\end{array}$ & $\begin{array}{l}\text { Total } \\
\text { Iron } \\
(\mathrm{mg} / \mathrm{l})\end{array}$ & $\begin{array}{l}\mathrm{Cl}^{-} \\
(\mathrm{mg} / \mathrm{I})\end{array}$ & $\begin{array}{l}\mathrm{SO}_{4}{ }^{2+} \\
(\mathrm{mg} / \mathrm{I})\end{array}$ & $\begin{array}{l}\mathrm{NO}_{3} \\
(\mathrm{mg} / \mathrm{l})\end{array}$ & $\begin{array}{l}\mathrm{NO}_{2} \\
(\mathrm{mg} / \mathrm{I})\end{array}$ & $\begin{array}{l}\text { Total } \\
\text { Hardness } \\
\text { (mg/l) }\end{array}$ \\
\hline $\begin{array}{l}\text { WHO (2011) } \\
\text { Limits }\end{array}$ & & $30-32$ & $\begin{array}{l}600- \\
1000\end{array}$ & 1000 & 0 & 100 & 50 & 0.1 & 0.3 & 250 & 250 & $50-100$ & 3 & - 500 \\
\hline NIS (2007) Limits & $6.5-$ & ambient & 5000 & 1000 & 10 & 0 & 0.20 & 0.2 & 0.3 & 250 & 100 & 50 & 0.2 & 150 \\
\hline
\end{tabular}

EC= Electrical Conductivity, TCC $=$ Total Coliform Count, TDS = Total dissolved Solids, WHO = World Health Organization, NIS= Nigerian Standard 


\section{DISCUSSION}

The result presented in Table 1 , indicates that the hydraulic properties in the crystalline basement area are lower than those obtained for the sedimentary area. Similarly, the yield recorded for the boreholes drilled in the basement terrain are equally lower with an average of less than $1 \mathrm{l} / \mathrm{s}$ compared to the values obtained from boreholes drilled in the sedimentary (Chad formation). It can be observed that the higher the transmissivity value the more productive is the boreholes. However, the higher the drawdown values, the less productive the borehole is. There is a good correlation between borehole performance, aquifer yield and the hydraulic conductivity. The hydraulic conductivity of the aquifer is controlled by the aquifer material and geology, for the sedimentary aquifer this is mostly made up of loose sandy and gravel materials that are more permeable resulting in higher hydraulic conductivity values when compared to the basement aquifer with poorly fracture network and thin weathered regolith aquifer materials comprising of clayey, Silty less permeable units derived from the insitu decomposition of crystalline rocks with lower porosity and permeability consequently given lower values of Conductivity. Generally, it can be noted that the higher the hydraulic conductivity the higher the yield and the lower the drawdown, hence the more efficient and productive the borehole and vice versa.

From the results obtained, the area can generally be considered to be of poor to low groundwater potentials when compared to results obtained from other areas with similar geological characteristics, as reported in Offodile (2002), a better yield of $6.3 \mathrm{l} / \mathrm{s}$ was obtained for a borehole drilled in the same Chad formation at Gumel with a depth of $106.1 \mathrm{~m}$, however Offodile gave a yield rangeof3.3 to $5 \mathrm{l} / \mathrm{s}$ for the Chad formation. For sedimentary Lafia sandstone aquifer in the Lafia sub basin, a yield of $12 \mathrm{l} / \mathrm{s}$ was recorded in a borehole at the LADP housing estate Lafia. In the upper zone aquifer of the southeast Chad basin, a yield of between 2.5 and 30 I/s was obtained in Maiduguri. Hamidu et al. (2015a) calculated an average transmissivity and specific capacity values of $1.70 \times 10 \mathrm{~m}^{2} / \mathrm{s}$ and $1.40 \times 10^{-2} \mathrm{~m}^{2} / \mathrm{s}$ respectively for the Gundumi formation in the Talatamafara area of Sokoto basin, northwestern Nigeria and a yield of $6.71 / \mathrm{s}$ was obtained for some boreholes located in both sedimentary formation and basement rocks in the area. Hamidu et al (2015b) calculated an average transmissivity and specific values of $3.83 \times 10^{-1} \mathrm{~m}^{2} / \mathrm{s}$ and $3.92 \times 10^{-1} \mathrm{~m}^{2} / \mathrm{s} / \mathrm{m}$ for the upper Bima sandstone aquifers of Kaltungo area with a borehole yield of as high as $6.6 \mathrm{l} / \mathrm{s}$. Comparing the result of this study with those obtained elsewhere, it is clear that there is great difference in the yields; this can in part be attributed to shallow depth which resulted in the boreholes having lower yields of less than $2 \mathrm{l} / \mathrm{s}$.

Low yield associated with basement aquifers can be attributed to low permeability originating from the absence of primary porosity, insufficient thickness of the water bearing regolith, low percentage fractures, distribution within the basement rock and the interconnectivity of conduits. Also the presence of alternating layers of clays, sand, clayey sands, silt and finer materials intercalation in the aquifers greatly reduce the yield of the aquifers. Bala et al. (2011) reported that the performance of regolith aquifer is affected by mineralogical composition, texture and structure of the parent materials.

Apart from the hydraulic properties which depend on the permeability of the aquifer material, poor borehole performance can result from poor borehole construction, design and completion. For example, gravel packing provides an annular zone of high permeability which increases the effective radius and yield of the well, Todd (1980) The size of the screen perforation play a major role in the free flow of water into the bore, the larger the diameter, the easier and the more water flow into the screen, however this in turn is dependent on the geological material forming the aquifer. If the screen is not placed on the faces of the water yielding formations the flow of water into the bore will be affected negatively. Finer to medium grained river sand or gravel are normally used as gravel pack material in boreholes with sedimentary sandy formation aquifers and weathered regolith aquifer while quarried rock chippings are used for gravel packing on fractured bedrock aquifer, any change could lead to lower yield and poor borehole performance.

A well design borehole should have highest yield with minimum drawdown, structurally stable, longlasting, efficient that can effortlessly allow the free flow of groundwater that is sediment-free from aquifer into the Well at the desire volume and quality and prevents also bacterial growth and material decay in the Well (Harter 2003). 
Water quality analysis revealed the presence of certain chemical components in the sampled groundwater; these chemical elements were dissolved into water as it travels through the soil and different geological formations during infiltration and percolation process. The quantity or concentration of these elements in the groundwater depends on the geological formation, surface area from which they are dissolved, solubility of minerals and the residence time in such formation Todd (1980). Also, according to Arabi et al. (2010a, 2010b) on groundwater quality around Gombe and environs in Benue trough, the variation in the chemical composition of groundwater may be due to leaching of terrestrial salts mostly within the Gombe formation, extensive use of fertilizers and ion exchange between soil minerals and water. Groundwater quality analysis shows that for the physicochemical parameters in the analysed water, it falls within the Nigeria standard organization NIS (2007) and the World health organization standard WHO (2011) permissible limit for safe drinking water, Tables 2 and 3.

\section{CONCLUSION}

The performance of Sedimentary and Basement aquifers within the southern Chad formation as determined by this study indicates poor aquifer performance resulting from low porosity and permeability of the basement aquifer and shallow boreholes drilled to a depth of less than $65 \mathrm{~m}$ in the Chad formation and the presence of low permeability Silt and Clay layers within the aquifers. Other reasons for the inefficiency and poor performance of the aquifers are poor borehole design, development and completion which lead to a very low average yield of less than $1 \mathrm{l} / \mathrm{s}$ for both sedimentary and basement aquifers with a yield average of $0.90 \mathrm{l} / \mathrm{s}$ for the area.

\section{REFERENCES}

Abubakar, Y.I. and Auwal , L.Y. (2012) Geoelectrical Investigation of Groundwater Potential of Dawakintofa Local Government area of Kano State, Nigeria. American international journal of contemporary research: vol. 2 no 9.P 188179.

Aghazadeh, N. and Mogaddam, A.A. (2010) The Hydrochemical Evaluation of Groundwater quality in Harzandat Aquifers, Northwest of Iran. The $1^{\text {st }}$ international applied geological congress, department of geology Islamic Azad University, Mashad branch Iran pp 464- 470.

Akaha, C.T. Promise, A.A (2008) Hydraulic properties from Pumping Tests data of Aquifers in Azare area, Northeastern Nigeria. J. app. Sci. Environ. Manage. JASEM. Vol: 12(4) pp67-72.

Arabi, A. S., M. Y. Kwaya and T. Maryam (2010a) Hydro-chemical study of groundwater from Northeastern parts of Gombe, North-eastern Nigeria, Journal of Geology and Mining Research Vol. 2(4), pp. 87-92

\section{RECOMMENDATIONS}

They Authors do recommend that in the future, both pumping and recovery test data be used to determine the aquifer properties of the boreholes in the study area and also the use of additional data is recommended. Also, a longer duration of the pumping test period should be increased to at least 24 or 48 hours so as to be certain that the real equilibrium is achieved and to also eliminate any chances of taking reading of drawdown from the wellbore storage portion of the graphs. For the Chad formation, there is the need to increase the depth of borehole to be constructed in the future so as to increase the chances of tapping deeper water bearing zones to increase the well performance and yield by increasing water inflow into the Well. As for water quality analysis a detailed and complete analysis of the chemical composition of water samples is recommended. This should include the entire major, minor and trace elements. It is also recommended that a standard design, construction and completion be adopted for all borehole construction activities in the studied area.

\section{Author's contributions}

The evaluation of hydraulic properties from the pumping test data, interpretation and the compilation of results were done by Hamidu Hassan. Geophysical survey (soundings), data interpretation and pump testing of the boreholes used for this study was carried out by Falalu Bello Halilu, while Abdullahi Ibrahim Mohammed, Abdullahi Arabi Suleiman and Mohammed Yarima Kwaya were responsible for editing, modifications and updating of Maps and water quality result interpretation.

Arabi, A. S., Funtua, I. I. , Dewu, B. B. M. and Alagbe, S. A. (2010b) Study of Suitability of Groundwater for Household and Irrigation Purposes in Parts of Adamawa State, Northeastern Nigeria ,International Archive of Applied Sciences and Technology, Vol 1 (2), 48 - 56: pp48 - 56

Bala, A.E. (2008) Optimum depth for Boreholes in Regolith Aquifer in parts of Northern Nigeria, Savana vol 21 no 1, $p$ 81-90

Bala, A.E., Eduvie, O.M. Byami, .J (2011). Boreholes depth and Regolith Aquifer hydraulic Characteristics of bedrock types in Kano Area, Northern Nigeria. African Journal of Environmental Science and Technology. Vol. 5(3), PP. 228-237.

Cooper H.H. and Jacob,C.E, (1946). A Generalized Graphical Method for Evaluating Formation Constants and Summarizing Well-field History. Trans-America geophysical Union 27. pp 526534. 
BAJOPAS Volume 10 Number 1 June, 2017

GSN (2006) Geologic and mineral Resources Map of Jigawa State, Nigeria.

Hamidu, H., Abdullahi, I. M.,Yelwa, N.A., Falalu, B.H. and Muhammed, D. (2015a) Comparative study of Groundwater resources in the Basement complex and Sedimentary terrain of Talatamafara town and environs, Zamfara state northwestern Nigeria: journal of Advances in Applied Science research 6(1):2733.

Hamidu, H., Abubakar, U, Abdulganiyu, I, Usman, M.B, Farida, .G.I (2015b) Groundwater resources evaluation of the Upper Bima sandstone aquifer, in Kaltungo area and environs, Northeastern Nigeria. Zaria geographer Vol, 22, No. 1, p 48-59

Harter, T. (2003) Water Well Design and Construction, FWQP reference sheet 11.3, ANR publication no.8086. publ. University of California. $6 \mathrm{p}$

Hazell, J.R.T,Cratchley, C.R., Jones, C.R.C. (1992) The hydrogeology of crystalline aquifers in Northen Nigeria and geophysical techniques use in their exploration

Kruseman, G. P. and de Ridder, N.A. (2000) Analysis and Evaluation of pumping test data second edition, Published by International institute for land reclamation and improvement. 372p.

Offodile, M. E. (2002): An Approach to Groundwater Study and Development in Nigeria Second edition. Published by Mecon Geology and Engineering Services Ltd. Jos, Nigeria.

Mohammed, I. (1984) Hydraulic properties of the Basement complex and Chad formation aquifers of Kano state based on test-pumping of selected boreholes. Unpublished M.Sc. thesis Department of Geology, Ahmadu Bello University, Zaria.

Nigerian Industrial Standards (NIS 554:2007) Nigerian standard for drinking water quality. 30p

NEW, M. and HULME (1997) Construction of 3 minutes latitude/longitude monthly climate surface over Africa for the period 1951-1995, climate research unit, University of East Anglia, Norwich.

Todd, D.K. (1980) Groundwater hydrology, pub.John Wiley and Sons New York Chichester Brisbane Toronto 535p.

UNEP/WHO (1996) Water Quality Monitoring- A practical Guide to the design and Implementation of Fresh water quality studies and monitoring Programmes. 22p.

Yelwa, N.A., Hamidu, H. , Falalu, B. H., Kana, M.A. Modabo, I.M (2015). Groundwater prospecting and Aquifer delineation using Vertical Electrical Sounding (VES) method in the Basement Complex terrain of Kumbotso Local Government Area of Kano State Nigeria. IOSR Journal of Applied Geology and Geophysics Vol. 3, Issue 1 Ver. I PP 01-06.

WHO (2006) Guidelines for Drinking- Water Quality first Addendum to third edition Vol.1 Recommendations. 595p

Wright, E.P. and Burgess, W.G. (1992) The hydrogeology of Crystalline Basement aquifers in Africa, geological survey society London special pub. No 66, 264p 